\title{
Thinking and acting 'outside the box': digital game and production of pedagogical affectations in teacher training
}

\section{Pensar e agir 'fora da caixa': jogo digital e produção de afetações pedagógicas na formação inicial de professores}

ID Marcio Roberto de Lima

iD Silvania Sousa do Nascimento ${ }^{2}$

\begin{abstract}
'Universidade Federal de São João del-Rei (UFSJ), Departamento de Ciências da Educação, São João del-Rei, MG, Brasil. Autor correspondente: marcinholima@ufsj.edu.br

${ }^{2}$ Universidade Federal de Minas Gerais (UFMG), Faculdade de Educação, Departamento de Métodos e Técnicas de Ensino, Belo Horizonte, MG, Brasil.
\end{abstract}

\begin{abstract}
In this article we track the effects of incorporating digital games to the initial teachers training in Physics during a course at a Brazilian public university. To this purpose, we used the production of empirical data from field observations and the preparation of reports by students during our Research-Action. We systematized our sources of information using open coding in the ATLAS.ti software and this result was discussed under the contributions of the Actor-Network Theory of Bruno Latour and collaborators. In our analysis, we identified the affectation of the pedagogical meanings of future teachers related to digital games and their incorporation into a proposal for teaching Physics.
\end{abstract}

Keywords: Physics teaching; Higher education; Digital games; Initial teacher training; Action research; Actor-network theory.

Resumo: Neste artigo rastreamos efeitos da incorporação de jogos digitais na formação inicial de licenciandos em Física durante uma unidade curricular em uma universidade pública brasileira. Para tanto, valemo-nos da produção de dados empíricos a partir de observações de campo e da elaboração de relatórios pelos licenciandos durante nossa Pesquisa-Ação. Sistematizamos nossas fontes de informações a partir de uma codificação aberta no software ATLAS.ti. Esse resultado foi discutido sob os aportes da Teoria Ator-Rede, de Bruno Latour e colaboradores. Em nossa análise, identificamos a afetação das significações pedagógicas dos licenciandos relacionadas aos jogos digitais e de sua incorporação em uma proposta de ensino de Física.

Palavras-chave: Ensino de física; Ensino superior; Jogos digitais; Formação inicial de professores; Pesquisa-ação; Teoria ator-rede.

Recebido em: 21/01/2021

Aprovado em: 24/04/2021 


\section{Introduction}

This article is an excerpt from a postdoctoral research", which associated the pedagogical incorporation of digital games to the initial teachers training in a Brazilian public university. Physics was the area of knowledge and training of nine undergraduates ${ }^{2}$ (three girls and six boys), who collaborated with our investigation. From this perspective, during our empirical intervention, we established relationships between the curricular aspect of that degree, the practice of future teachers and contemporary culture.

In the form of an Action Research (THIOLLENT, 1996), this study articulated practices and typical elements of a digital culture (HEINSFELD; PISCHETOLA, 2017; LEMOS, 2020; LIMA; MENDES; LIMA, 2020; REIS; SCHNELL; SARTORI, 2020; SANTAELLA, 2015) to the disciplinary content of the teacher's training of undergraduate in Physics, transcending prescriptive propositions and fostering new meanings in the construction of knowledge and pedagogical skills with/in digital medias, especially from digital games and their conceptual and design elements.

Although it is not a totalized and homogeneous issue, when we turn our attention to everyday life, it is imperative to recognize the existence of multiple forms of communication, access and production of information from telematic networks. These different courses of action in the contemporary world indicate an expansion of the ways of acting in society and, fundamentally, of our relations with knowledge. Thus, we can admit that we are experiencing a continuous process of reconfiguration of human activity from the gradual social appropriation of Digital Technologies of Information and Communication (DTIC) (LIMA, 2015). Understanding that this finding goes far beyond the possession of electronic artifacts and signals changes in habits and ways of being in the world, we converge on a new modus vivendi that expresses a digital culture.

Likewise, it is important to note that the propagation of this culture poses adversities that refer to the demands of digital inclusion, the risks associated with surveillance in cyberspace, security of personal data, prediction and modulation of behavior in/from digital platforms, etc. Even so, the contemporary socio-technical scenario highlights the relevance that DTIC assumes as mediators of our activities. This is perpetuated "[...] not only in everyday life, but also with regard to the forms and possibilities of academic learning" (MORAES; LIMA, 2018, p. 300, our translation), requiring new ways of thinking about education and its formative processes in the face of this digital ecology. Therefore, it is substantial

[...] to articulate the social context to educational processes, not neglecting the typical languages of digital culture. Thus, we see the educational field as a space for problematization in the face of the demands of this culture, seeking to understand inherent reconfigurations and undertake new ways of educating. (CRUZ; LIMA; NASCIMENTO, 2020, p. 119, our translation).

With this in mind, we recognize that digital games stand out among the most popular and expressive products of digital culture (NEWZOO, 2020) and we assume the proposition that these artifacts can favor the creation of new teaching and learning environments,

${ }^{1}$ The research has a Certificate of Presentation for Ethical Appreciation, filed and approved by Plataforma Brasil under number 18926819.1.0000.5149. All undergraduates' names mentioned in the article are fictitious.

${ }^{2}$ The term 'undergradute' is used in this paper meaning that the person (future teacher) is in the process of professional training in higher education, whom will be able to teach in Brazilian basic education. 
leveraging new avenues of knowledge building. Thus, based on the contributions of the Actor-Network Theory, by Bruno Latour and other collaborators, the objective of this work was to track the effects of the pedagogical incorporation of digital games in a teaching proposal during a curricular internship subject of an undergraduate in Physics.

\section{Basing our way of investigation: some concepts of the actor-network theory}

According to Lemos (2013), the Actor-Network Theory (ANT) was articulated from Science and Technology Studies, in the 1980s, having as main exponents Bruno Latour, Michel Callon, Madeleine Akrich, Michel Serres, John Law and Wiebe Bijker among others. To characterize his sociological approach, Latour (2012, p. 24, our translation) warns us about the etymology of the word 'social' and points out that the Latin socius refers to an 'associate', stating that: "[...] in different languages, the historical genealogy of the word 'social' means first 'following someone' and then 'enlisting' and 'allying with' to finally express 'something in common'". Thus, Latourian's 'social' approach involves a careful process of observing a scene of interest, which underlies a mapping of entities in association, in order to identify emerging agencies and transformations.

As a result, Latour (2004, p. 397, our translation, emphasis added) also assumes ANT as a 'sociology of associations', whose analytical field aims to "[...] follow things through the networks in which they transport themselves, describe them in their plots [...] [and] study them [...] symmetrically [...]". However, after all, what are these things? How to understand network? What does it mean to describe and study things symmetrically? Understanding the answers to these questions is what justifies our adherence to Latourian propositions as the analytical basis of this study.

It is necessary to recognize a certain strangeness regarding the proposition of 'follow things'. After all, something that can be followed is something that travels along a path and, in doing so, leaves a trail. Therefore, such 'things' refer to what is capable of undertaking and, at times, promoting transformations in its path. In fact, when proposing 'following things', Bruno Latour (LATOUR, 2004) mentions what takes shape and produces meanings in an associative relationship, evoking the concept of actants, which refers to the term 'actor' in the expression 'actor-network'. However, Latour (2001) explains that 'actor' has a meaning restricted to humans, with the use of actants being preferable ${ }^{3}$.

Thus, an actant is one that generates actions and produces movement and difference, being it human or non-human (LEMOS, 2013). It is essential to indicate that, in ANT, actants are defined by their action field (LATOUR, 2001) and, therefore, by the affectation of the associations in which they are found. To be coherent with this point of view, an actant cannot be priori defined which would refer to an essence. On the contrary, an actant configures itself in the relationship and when changing a given circumstance, becomes perceptible/traceable by producing some difference, affecting and being affected.

${ }^{3}$ In an exercise in understanding the concept of 'actants', thinking of a teacher and his lesson plan. In association, these two actants evoke many others, such as: school, classroom, curricular guidelines, political-pedagogical project, computers, teaching materials, students and school administrators. 
It is from this that we come to recognize an actant, sometimes as a mediator, sometimes as an intermediary. An actant is called a mediator when he modifies a state of affairs in which he is involved; that is, "[...] mediators transform, translate, distort and modify the meaning or elements they supposedly convey" (LATOUR, 2012, p. 65, our translation). An intermediary actant, on the other hand, composes associations in an almost invisible way, not substantially altering the network to which it is linked. However, an intermediary can become a mediator, and vice versa ${ }^{4}$.

In order to understand the concept of network, which is also part of the expression that defines the Theory, it is essential to clarify that

[...] network is not the structure, infrastructure or sociability, it is not the place where things pass, move or are deposited, but the place where relationships are established and transformed. The network is the movement of associations which form the social [...]. (OLIVEIRA; PORTO, 2016, p. 64, our translation).

In this way, the social is a consequence of the actants' agency, which form dynamic networks: "[...] More than explaining the phenomena having society or the social as a cause, the [Actor-Network] theory will place them as a consequence of circulation in socio-technical networks complexes leaving no watertight or separate field as a category" (LEMOS, 2013, p. 3, our translation). In other words, the idea of a network has to do with movements of associations that "[...] refer to flows, circulations and alliances, in which the actors involved interfere and suffer constant interference" (FREIRE, 2006, p. 55, our translation).

It is exactly in this that stands out what Latour (2001, p. 356, our translation) qualified as translation, that is, "[...] the work thanks to which actors modify, displace and translate their various and contradictory interests". Therefore, in the analysis of networks from the perspective of ANT, the effects of translations are of special interest. It is from them that the power games emerge between the actants which, when working together, produce transformations (SISMONDO, 2010) and evidence of a latent social. All of this reinforces that an actant is defined by its performance in a network, that is, its performance, which, according to Latour (2012), is the focus of an ANT study. This position is in line with what Sørensen (2009) - taking into account the indications of Law (2002) - assumes as performance: effects that reverberate from the interrelationships established in a socio-material assembly.

In its symmetry principle, ANT is assumed by Latour (2012) as a flat ontology that breaks the separation between subject and object. In this configuration, ANT moves away from structuralist sociology and its theoretical frameworks that explain the social. Alternatively, assume that humans, animals, plants, objects, institutions, laws, etc. establish living connections and, in a network, they produce work.

Instead of examining only human actors, their individual skills and their social inter-relationships, a sociomaterial view treats the social and material elements of knowledge practices as entangled and mutually constitutive. Materiality is particularly highlighted, revealing ways that bodies, substances, settings and objects combine to actually embed and mobilise knowledge, materialise learning and exert political capacity. (FENWICK, 2014, p. 265).

${ }^{4} \mathrm{An}$ example: in a videoconference, a computer in perfect working order is configured as an intermediary, but, if at any moment it crashes, it assumes the condition of mediator. This change in the status of the actant (computer) is due to the destabilization that it caused in the flow of actions in which it was affiliated, producing reactions and mobilizations. 
We realized, then, that ANT assumes that humans and non-humans retain agency potency in associations. This proposition reinforces the prerogative of symmetry in networks of actants, but it can lead to the inevitable question: how can a (non-human) object be endowed with agency if it lacks will? It is Bruno Latour himself (LATOUR, 2012, p. 108, our translation, emphasis added) who leads us to reflect and forward a position:

If the action is limited to what humans do in the 'intentional' or 'meaningful'
way, it is not conceivable how a hammer, a basket, a lock, a cat, a rug, a mug,
a timetable or a tag can act. [...] our questions regarding an agent are simply
these: does it make a difference in the course of action of another agent or
not? Is there any proof by which we can detect this difference?
The common sense answer would be a loud 'yes'. If you can, with the utmost
tranquility, sustain that driving a nail with or without a hammer, boiling water
with or without a pot, transporting food with or without a basket, walking in
the street with or without clothes, zapping the television with or without the
remote control, stopping a car with or without the brake, taking an inventory
with or without a list, running a business with or without accounting are exactly
the same activities, that the introduction of these common implements doesn't
change anything 'important' in completing tasks, then you're ready to visit the
Faraway Land of Social and disappear from here. For all other members of
society these implements make a lot of difference and are [...] participants in
the course of action [...].

Thus, our understanding is that - in symmetry - humans and non-humans act with each other, expressing themselves in a network. However, it is essential to consider that this "[...] symmetry is not ethical (things are worth the same as humans), but analytical (things make us do things and have important implications)" (LEMOS, 2014, p. 6, our translation, emphasis added). This same perception can be identified in Coutinho and Viana (2019), who, when commenting on the work of Knappett (2005), explain that the symmetry established between humans and non-humans in a work based on the ANT is an analytical option to record the characteristics established between these actants without giving greater weight to one or the other pole.

In this view, ANT rejects a separatism between actants and a hierarchy that places them on different analytical planes. Therefore, we consider it essential to admit the human being as a hybrid that has always been culturally involved in technical objects.

The human, as we can understand now, can only be captured and preserved if we give it back this other half of itself, the part of things. As long as humanism is made in contrast with the object abandoned to epistemology, we will understand neither the human nor the non-human. (LATOUR, 1994, p. 134, our translation).

With the same conception, Lemos (2013, p. 130, our translation) tells us "[...] the human is [...] formed by historical processes of mediation [...]. It is precisely the network (and not the individual) formed by everything that is associated, was associated or will associate". Yet, "[...] we (human beings) are a hybrid collective that does not exist without things" (COUTINHO; VIANA, 2019, p. 24, our translation). Thus, we understand that it is from our links with non-humans that we form our subjectivity and our understanding of the world, which ends up revealing that networks are established from heterogeneous relationships and this is where the social emerges. 
Once some of the concepts of ANT are presented, it is still worth exploring its methodological treatment of issues of interest. The orientation starts from

[...] 'following the actors themselves', that is, trying to understand their innovations [...], in order to discover what collective existence has become in their hands, what methods they developed for its adequacy, what definitions would better clarify the new associations which they were forced to settle down. (LATOUR, 2012, p. 31, our translation).

These investigative procedures are linked to an immersion in the research field bearing in mind: (1) the recognition of actants - who/what does integrate the studied situation?; (2) the mapping of associations between actants - what starts to circulate in the situation studied? and (3) the identification of mediations - which translations took place in the studied network? Thus, an ANT study assumes the configuration of an analytical-descriptive report, which explains the social that made up the scene of interest investigated. In the words of Latour (2012, p. 180, our translation), fed by the uncertainties surrounding the actions of the actants, "[...] the idea is simply to bring to the foreground the very act of composing reports". From this perspective, the author warns that "[...] no researcher should find the task of describing humiliating" (LATOUR, 2012, p. 199, our translation).

Even though ANT was conceived in a different field of Education, we reiterate that its theoretical-methodological concepts and propositions are adherent and opportune to the interests of research in this area of knowledge. After all, educational processes are hybrid and their materiality - laws, rooms and laboratories, curriculum, assessments, equipment, teaching materials, people, etc. - is essential to the task of educating. In other words, ANT makes visible "[...] great diversity of things that are at stake in educational environments, provides the identification of non-human agencies [, the] associations between different entities and the effects of these interactions" (VENANCIO; VIANA; SILVA, 2020, p. 5, our translation). Far from defending technological determinism, we prefer to recognize that, if objects do not educate by themselves, without them we do not produce Education.

\section{Research in action: methodological orientation and corpus design}

This investigation was conceived from an Action-Research (THIOLLENT, 1996), characterized as a study carried out in collaboration with members of an educational community. From this perspective, our empirical intervention strategy aimed to foster changes in the network of actants studied. It was designed and implemented in partnership with the postdoctoral supervisor, a supervising professor of curricular internship and with nine teachers' training of undergraduate in Physics at a Brazilian public university. In this line, we integrate ourselves to the studied network and we associate with other actants, putting into circulation issues of interest (LATOUR, 2012) for the investigation. We understand that this research encouraged the valorization of the actants' agencies, allowing us to capture nuances of the pedagogical experience produced.

Considering the research outline of this article, the composition of our analytical corpus integrated two data generating sources: the records of observations of synchronous discussions mediated by DTIC and, fundamentally, the content of the 
individual reports that made up the final assessment of the undergraduates' curricular internship. Taken together, these primary sources formed the basis of our ANT-based discussion (LATOUR, 2012).

In order to track the effects produced by the pedagogical incorporation of digital games in a teaching proposal during a curricular internship subject of a teacher's training of undergraduate in Physics, we used strategies mediated in the open source ATLAS.ti software. In this sense, based on the guidelines of Strauss and Corbin (2008), our codification of data prioritized issues of interest (LATOUR, 2012), which emerged from the corpus from a view shared by the undergraduates: "[...] It is as if we said to the actants: 'We're not going to try to discipline you, fit you into our categories; we will let them stick to their own worlds [...]'" (LATOUR, 2012, p. 44, our translation).

Thus, during the readings and exploration of the corpus, we were attentive to the mapping of actants, the associations established between them and the effects produced in the network. In this procedure, two analytical categories were constructed: initial meaning and transferred meaning from/by the students about digital games and their incorporation in a teaching proposal.

In the next section, we turn our attention to the expression of what Latour (2012) encouraged us to do as a result of an Actor-Network study: the report of the studied social. To do so, we start from a rescue of details of the intervention carried out and present the results of the mapping of actants and their network of associations, as well as a discussion of the effects produced based on the indicators of our empirical categories.

\section{Results and discussion: intervention space-time and its effects}

Due to the Corona Virus Disease pandemic (COVID-19) and the implementation of the Remote Emergency Education (REE) regime at the university where we developed our study, the empirical intervention stage was carried out between 08/04/2020 and $10 / 27 / 2020$. The last week of the semester was dedicated to the functions of recording academic performance and closing journals on 11/07/2020.

The construction of an intervention strategy in the field can be considered as the basis of an Action-Research. Thus, our initial focus was its planning in terms of format, content, objectives, practices and evaluation. Among the legally applicable alternatives to the REE regime, we chose to develop our activities synchronously and asynchronously, in an interdependent and complementary manner, and through the university's virtual institutional platform (Moodle).

During the period, an REE plan was put into action, which totaled 14 synchronous virtual meetings with academics. The intervention strategy included the formal presentation of contents related to the theme of digital games and teaching processes, as well as an internship practice mediated by a digital game developed by the students.

The structure of the REE classes was designed so that all students could freely express their anxieties, doubts and desires to compose a teaching practice for the internship. We also register that the academics' suggestions and decisions were discussed and accepted, consolidating a work built with openness and in partnership. With due monitoring and support from professors-researchers, the grouping of undergraduates was encouraged throughout the semester, aiming at the composition of 
action fronts in the internship that was part of the curricular unit (CU). In this configuration, as we interacted with a relatively small class, communication was favored by the DTIC and this did not aggravate the difficulties inherent to the REE.

As the semester was condensed into three months, the workload of the CU was distributed in weekly synchronous meetings, asynchronous assessment activities related to the theoretical axes that made up the internship planning and practice. All the proposed activities had the adhesion of nine undergraduates, who were successful at the CU. The remote didactic arrangement was facilitated: (1) by the possession and appropriation of the DTIC by those involved; (2) by the constant presence and performance of professors-researchers with the undergraduates; (3) through the link of an internship supervisor professor who accompanied and collaborated with the development of the practical part of the $\mathrm{CU}$; $(4)$ by the legal support of the REE regulations; and (5) for the engagement of all those involved.

It is important to note that the teaching plan was fully implemented, but in a way that is different from the typical linearity of a semester of physical presence in academic spaces. With the REE, the dedication to the discipline and practical activities of the curricular internship took on a contour that does not allow for rigid boundaries of a linear chronology and exclusively constituted in synchronous activities. In the course of the designed activities, different fields of action were assumed by the undergraduates together with the professors-researchers and the curricular internship supervisor, emerging autonomy, commitment and protagonism as essential elements for the success of the proposal mediated by DTIC.

Specifically, the period of internship guidance and supervision was intensified in its regime of proposals, definitions, overcoming insecurities and collective work. Numerous fronts made up this moment of transformation for students, who, like us, experienced an unprecedented situation in their academic trajectory: a semester fully mediated with DTIC and with equally remote internship field activities. Our assessment, as professors-researchers and together with the external supervisor of the internship, was that the grouping of students was successful in the activities undertaken.

Figure 1 is the result of a mapping of actants and their traces of associations over an academic semester at a university. Academic daily life was exceptionally affected by the presence of SARS-COV-2 (severe acute respiratory syndrome coronavirus 2) which forced the establishment of a regime of social distancing, since this actant has a high potential for infection and lethality. In particular, SARS-CoV-2 brought about reconfigurations in the administrative sphere of the university and provoked adjustments in the educational legislation, which established an REE regime due to the COVID-19 pandemic. Consequently, these changes required the re-elaboration of our teaching plan and reconfigured the format of interactions between: undergraduates, professors-researchers (authors of this article), professor-supervisor and their high school students during internship field practices. Respecting educational legislation and health recommendations, the work among these last actants was mediated by DTIC. In this context, we - the professors-researchers - undertake, together with the teacher's training of undergraduate in Physics, moments of discussion about the theoretical framework of digital games and its possible association with the practice of teaching in the internship field. Thus, our work at CU included: planning and construction of a digital game by the undergraduates; guidelines relevant to the 
design and implementation of this game; and evaluation of a teaching practice in the internship field. This practice was accompanied by a supervising professor of the curricular internship, who chose the topic of electrostatics as a referential content of Physics to be explored by undergraduate students with high school students. The theme chosen by the professor-supervisor of the curricular internship guided the narrative materialized in the digital game.

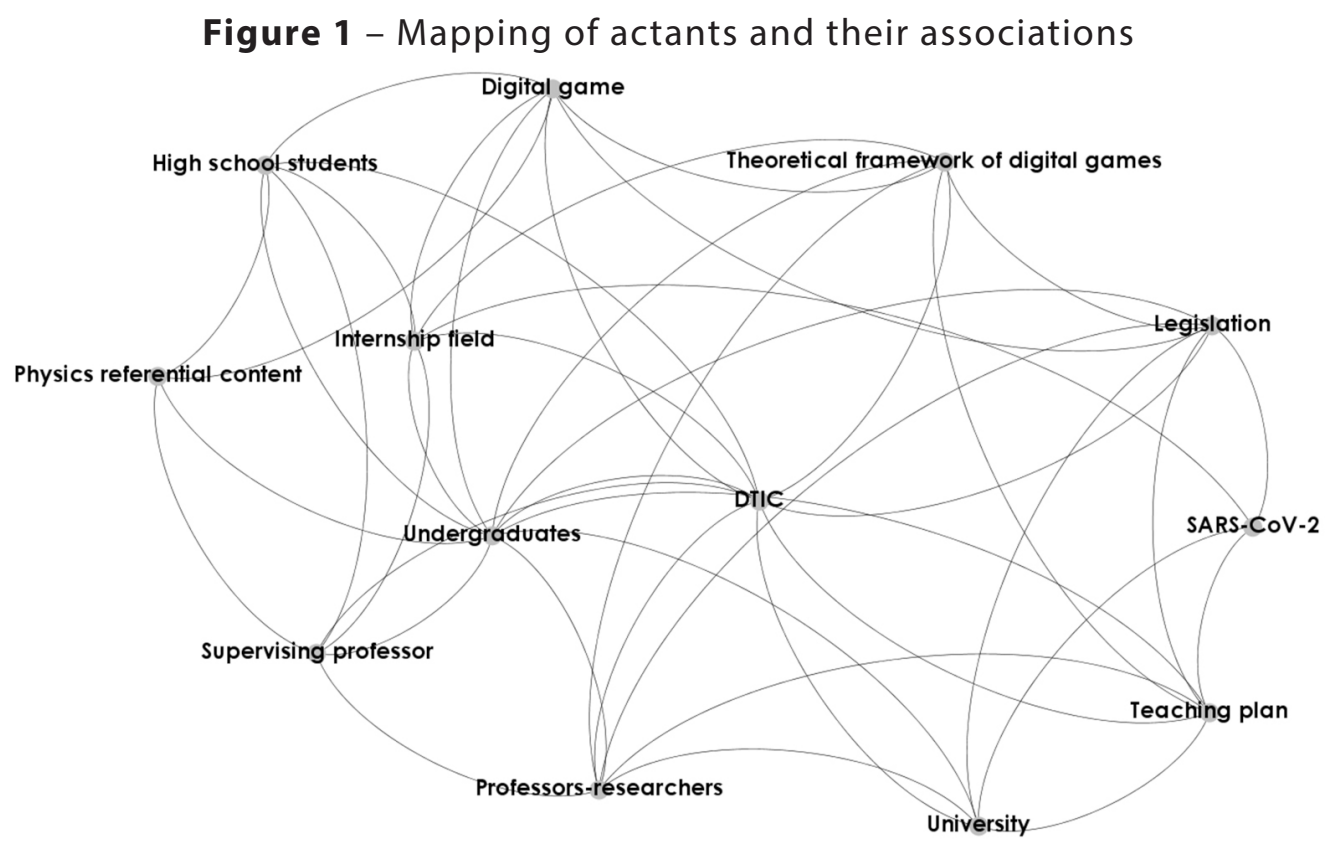

Source: prepared by author Marcio Roberto de Lima from research data in the Gephi software.

The steps subsequent to the mapping of actants and their associations were dedicated to translations (LATOUR, 2001) carried out in the network. Attentive to the traces of actions linked to the production of a digital game by the undergraduates and its integration to the teaching proposal of the curricular internship, it was possible to make visible effects produced in the network, which characterized the performance (LATOUR, 2012; SØRENSEN, 2009) of the transition of pedagogical meanings of undergraduates related to digital games and their association with the teaching of Physics.

Based on our first empirical category - Initial meaning -, we could see, among most undergraduates, a skeptical position regarding the association of digital games with a teaching proposal. Among the nine undergraduates who attended the $\mathrm{CU}$, only two (Bia and Ari) declared to have some experience with such an association. Both cases had, in the Kahoot ${ }^{5}$ environment, their form of development, and these teaching actions were positively evaluated by those undergraduates. From our field observation records, we identified that undergraduates Eva and Gil expressed distrust and incipience to promote a game-teaching integration. In the same sense, other traces were identified at different times in the internship reports of other undergraduates:

\footnotetext{
I was a staunch skeptic of proposals involving games and the classroom. I recognize that my skepticism was due in large part to my ignorance and lack of knowledge on the subject [...]. [Undergraduate Max, emphasis added].
}

${ }^{5}$ Kahoot is an online multiple choice quiz creation platform. 
During my internship experience, before planning the intervention proposal, many questions arose regarding the possibility of [...] incorporating electronic games in teaching [...]. [Undergraduate Ema, emphasis added].

I found it very difficult [...] to be able to make the connections between the game and a teaching strategy and also with a lesson plan. I thought it was not possible [...]. [Undergraduate Tom, emphasis added].

The use of games in teaching [...] was unthinkable for me [...]. [Undergraduate Rui, emphasis added].

Despite [playing] often and for many years, I had never thought about his role in teaching. [Undergraduate Eli, emphasis added].

All these positions and excerpts were referenced in our empirical category initial meaning and these occurrences indicate insecurities on the part of the undergraduates regarding the pedagogical potential of digital games. The undergraduate Max, for example, explains a justification for his skepticism: the lack of knowledge about the subject. Therefore, the reference content of our CU would need to configure itself as a mediating actant, so that, from its circulation on the network, a new representation in relation to the theme could emerge (COUTINHO et al., 2014).

The undergraduate Ema, on the other hand, highlighted a reflective process involving the subject of $\mathrm{CU}$, which is highly desirable in training actions. It is characterized that the intervention of our research evoked a formation of meanings around what was learned and, thus, fostered a dynamic that refuted assuming the undergraduates as watertight/stabilized entities. On the contrary, our commitment was to provoke a break in inertia, inciting movement and work that reverberate as performance (LATOUR, 2012; SØRENSEN, 2009) based on associations between humans and non-humans (VENANCIO et al., 2020).

In the grouping (LATOUR, 2012) formed by undergraduates Tom, Rui and Eli, the issue of pedagogical incorporation of digital games is found in the field of the impossible (Tom) or, in a similar sense, the unthinkable (Rui and Eli). Furthermore, as we turn our attention again to the field observations and the five utterances presented, it is notable that the verbs used by the undergraduates have been in the past tense. This puts us in front of a trail that evidences the reports as representations of a constructed reality (COUTINHO et al., 2017) from previous associations.

However, ANT (LATOUR, 2012) encourages us to face networks in a fluid, changeable way and with impermanent associations. Thus, the relationships between actants during the school semester were subject to mutual influence relationships, which led to affectations and ended up causing translations (LATOUR, 2001). So, returning to our corpus, we ask: what translations have taken place in the network in order to bring out a new performance of the pedagogical meanings of undergraduates related to digital games and their association with the teaching of Physics?

One of the expectations of the Action-Research intervention, in addition to the affectation of pedagogical meanings about digital games by the undergraduates, was related to the practice of internship in teaching Physics. As teacher-researchers, we were aware of all the time constraints and also those inherent in the REE, including those involving the internship field. Even so, we encouraged the group to value the opportunity to put into circulation some of the elements of the theoretical field, which we had discussed and matured in the discipline, prioritizing the involvement of a digital game as a mediator of teaching in the curricular internship. 
At this point, it is essential to rescue the indications of Egenfeldt-Nielsen (2011), who explains that it is possible to learn by making games, which involves a game design and implementation (with or without educational purpose), which systematizes a certain knowledge, exploring it in the form of a game. This last perspective was the course of action chosen by the group of undergraduates we worked with.

To start the digital game project, it was necessary to start from a reference content of the Physics high school curriculum. The indication of the theme 'Electrostatics' arose from a negotiation with the supervising professor of the curricular internship, who claimed the need to work on the theme in his classes. We reiterate that the lack of time marked this stage of our intervention and brought limitations, since it was imperative to reconcile the graduation calendars at the university and the classes at the basic education institution where the practice with the digital game would take place under supervision.

Setting the theme, undergraduates began a collective and collaborative work in the design and development of the digital game. This was another feature that emerged from the REE: an internship carried out in a group and based on a collective project. Therefore, undergraduates have taken different roles: project manager, programmer, content research, content editor and designer. In this aspect, Coutinho (2018, p. 5, our translation) warns that the most important aspect of this dynamic is related to "[...] the skills, knowledge and skills acquired during the development of the project", which we could see during the curricular internship.

It was in this configuration that academics started discussions and multiple fronts of implementation. Obviously, a process of negotiations and definitions had begun, which did not happen linearly and homogeneously, with tensions and the need for revisions, flexibility and adjustments arising. That is, "[...] collective phenomena emerge through the work of the participants, and extend as far as the actors carry them, and last as long as they can withstand it" (LATOUR; VENTURINI, 2019, p. 40, our translation).

One of the controversies revealed to us by the undergraduates involved the indispensable definition of the game's narrative, which would involve the Electrostatics theme. Based on a previous experience, the undergraduate Bia suggested working on this topic based on electricity in living beings. In collaboration, undergraduate Max suggested an adaptation using the idea of metamorphose as in the Ben $10(2020)^{6}$ character style, in which the player could transform into a living being assuming powers to save the world in danger. From this movement, the grouping reached the definition of a line for a first version of the game's narrative.

Still, in a very short time, the grouping positioned themselves and presented us with an unfinished prototype using an unconventional platform: an interactive PowerPoint. In one of the synchronic meetings, the undergraduates expressed doubts, were unhappy with the platform used to compose the initial idea, and presented conflicts inherent to a collective work. Provoked by the professors-researchers regarding the need to be aware of fundamental elements involving gameplay and, mainly, the game's narrative, the group resumed the debate and revision of its action plan. As advisors, we proposed that the narrative could consider the composition of

${ }^{6}$ Ben 10 is a boy character who wears a wristwatch-like device, which allows him to transform into alien creatures. 
an inventory, which could be formed from the player's successes throughout their interaction in the environment. This was welcomed by the undergraduates.

At that time, two of the undergraduates (Eva and Ema) were willing to invest in the migration of the development platform to Scratch ${ }^{7}$ or Construct ${ }^{8}$, in addition to reviewing the narrative based on new ideas. The other members of the group turned to readjust the reference contents to be incorporated into the digital game. The chosen platform was Construct, and a preliminary version was structured and presented collectively in a later synchronous meeting.

The project had evolved a lot and gained in gameplay and aesthetic elements. After a collective analysis of the game in a new synchronous interaction, we decided that the project would follow that format. The sequence of actions taken by the undergraduates involved refinements in game control, audiovisual improvements, content review and its accommodation in the user interaction environment. The final format of the proposal took on the materiality of a digital game - Ampets ${ }^{9}-$, which considers the collection of items based on correct answers to questions related to electricity in living beings. To consolidate their inventory, the player needs to be informed in the digital game environment about the electrical properties of some living beings and, later, analyze situations involving the studied contents, as well as make associations correctly in the proposed questions.

Returning to our corpus, the indicators of our analytical category translated meaning allowed us to identify that, from the interactions established between the actants, a translation of meanings about the pedagogical incorporation of digital games in a teaching practice emerged. We note that this initial positioning 'skepticism' (among others) had been affected and another reality produced taking into account the new associations established in the network as indicated by the undergraduates:

[...] I knew that digital games could be implemented in teaching, but I was not aware of how this was possible [...]. With classes, reading articles and game production, I got deeper into these issues and I was able to better understand the aspects that make up this feature [digital game] and how it is also important in promoting digital culture. [Undergraduate Bia].

[...] [l already] knew the importance of games in intellectual and physical development [...], however [the experience at CU] made me have a different perspective on the subject, mainly on teaching [...] I think it's a fair and very valid proposal [...], but this is a complicated process that demands a lot of time and creativity, especially from the teacher who intends to implement it [...] in order to be able [...] to complete [...] his objective [education]. [Undergraduate Ari].

The pedagogical use of games [...] can be very beneficial in the teaching and learning process, there are several skills that can be worked on and developed [...]. The experience of planning and applying an internship proposal with [a digital game] was quite unusual and significant for me. This type of activity [...] demands time, research, creativity and reflection on its meaning. [Undergraduate Bia].

It made me understand the need to look for other ways to signify what I am studying so that my associations are not limited, but expanded. [...] The method must be thought out very rigorously and, priorly, it is quite complex to unite the teaching of key concepts in basic sciences, for example, to a game. [Undergraduate Gil].

\footnotetext{
${ }^{7}$ Free programming community for kids.

${ }^{8}$ Game creation software.

${ }^{9}$ The name Ampets suggests a play on 'Amperes' and 'Pets' and was chosen by the undergraduates. The game can be accessed on https://cutt.ly/tWCOyg6.
} 
[Everything that was experienced at CU] helped a lot to open my eyes in relation to games [incorporated into] pedagogical practice. [...] studying this theme [...] changed my way of seeing the world. [Undergraduate Max].

[the digital game incorporates] visual, auditory and narrative resources and [enables the development of] skills [...] including motor coordination, logical reasoning, [decision making], among others. [Undergraduate Ema]..

I was surprised [...] [and] the game's implementation gave me access to learn tools that [gave me] autonomy to develop other similar interventions [Undergraduate Tom].

[...] it was a very rich experience of collaboration and exchange of ideas, we had little time to build [and] several difficulties [...]. The use of games in teaching [...] is something viable when there is direction and good planning. [Undergraduate Rui].

[...] internship III was the most important in my training as a teacher. In addition to the practical factor, the theoretical content of the internship was what interested me the most [...]. With the classes [...] I could have contact with the work of several researchers [...] who showed me that [the digital game can be incorporated] in the classroom with great success. [Undergraduate Eli].

Considering this (new) view shared by undergraduates, we find in Coutinho et al. (2017) the explanation that, through the composition of new bonds, other actants are mobilized and a new state of the world comes into being. This proposition took on strength with the report of the undergraduate Bia, who stated: "Many colleagues, at the beginning of the course, were skeptical about digital resources and games and I could see the change of opinion during the classes, which was very interesting". Figure 2 represents the realities produced by the undergraduates at the beginning (Initial meaning) and at the end of the semester (translated meaning).

Figure 2 - Effects of the pedagogical incorporation of a digital game by the undergraduates

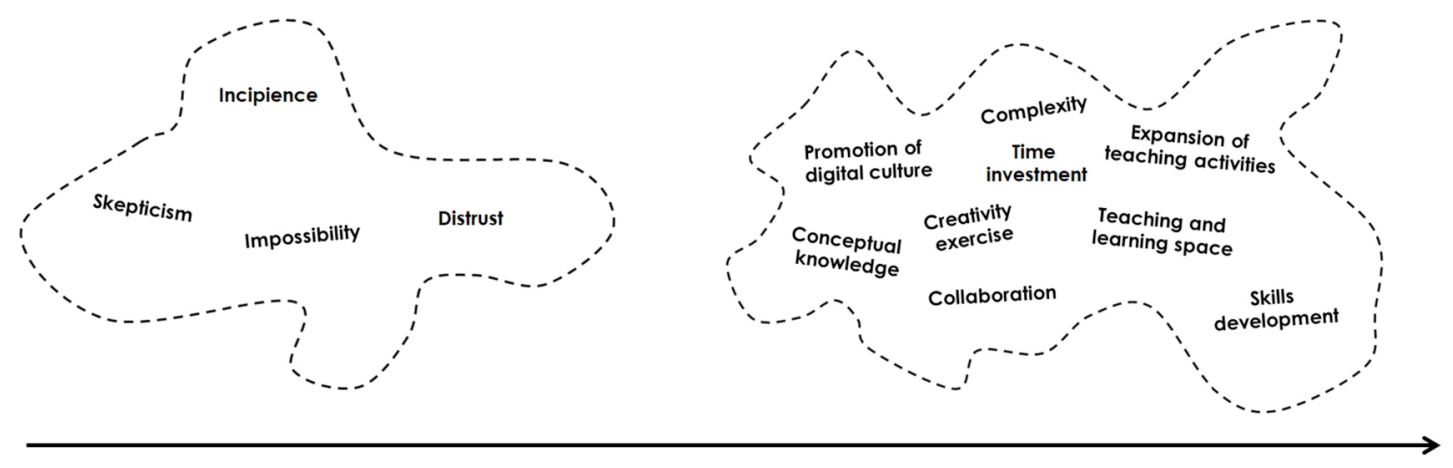

Source: elaborated by author Marcio Roberto de Lima from research data.

The mobilization of undergraduates around the contents, the proposals of the CU teaching plan and the demands of the supervised internship caused displacements and induced instability in the network of actants. The positions of the graduates were destabilized as the readings, activities, debates and, especially, the production of the digital game at $\mathrm{CU}$ took place. As they circulated on the network, these experiences were shared by the actants, which started an ongoing reconfiguration process, which favored the establishment of new pedagogical meanings, provided a break with previous representations and gave rise to a new modus vivendi. 


\section{Conclusion}

The main objective of this study was to track the effects of the incorporation of digital games in a teaching proposal during a curricular internship subject of a teacher's training of undergraduate in Physics at a Brazilian public university. Therefore, the course of our Research-Action promoted an empirical incursion, which favored debates around specialized literature, guidelines on teaching practice and the construction of a pedagogical product in a digital game format by the undergraduates.

We learned that the Actor-Network Theory renews the meaning attributed to the term 'social' assuming it as an association of actants, which, as a hybrid collective, promotes a flow of transformations, which highlight issues of interest. Thus, in our intervention in the research field, we strive to track the translations established in the mapped network and we are nourished by the uncertainties that the moment experienced gave us. With this view, in our report, we tried to weave a network that evidenced a space-time of reflections and affectations. It is impossible not to recognize the importance of materiality in the studied collective, as, without it, the observed transformations would not take place. In addition, we do not confer an illusory stability to the reality that we elaborate with the other actants in our network and, in another sense, we prefer to assume the impermanence and typical fluidity which characterize any grouping.

From this, it was possible to understand that the materiality of the digital game produced by the undergraduates encompassed a process of translation of the pedagogical meanings of the students related to digital games and their incorporation into the teaching of Physics. The mapped affectations departed from a place of skepticism, incipience, distrust or even impossibility of approximating 'game-pedagogical practice' to a status, which started to include: (1) game as a cultural product; (2) game design as a complex process that involves time, creativity, theoretical references, agencies, etc.; (3) development of a digital game as a form of collective and collaborative work; (4) digital game as a way to include digital culture in the school space; and (5) digital game as a space for teaching and promoting learning and skills.

Likewise, we recognize limitations that permeated the entire period of REE and that ended up interfering in the production of the digital game. Even so, we do justice to the efforts of the undergraduates in building an audiovisual product, which, although with simplified mechanics, added Physics reference content in a planned manner and adherent to a teaching proposal chosen by the internship supervisorteacher. If the trace of an artifact, which still lacks maturation, is present in the elaborated digital game, the proposal - as a whole - also reveals a translation of the pedagogical tradition and, equally, of the way of thinking about student performance during a supervised undergraduate internship.

Finally, we register that our intention was not/is to promote a replacement of methods or, still, to treat digital games as a panacea for (many) educational problems. For us, it is important to encourage the approximation of the products of digital culture to the pedagogical practices of teachers, substantiating them. Furthermore, when we introduced this theme in initial teachers' training, we could see how mobilizing and enriching an authoring process can be, involving the articulation of curriculum 
content, digital game design and teaching practice. Thus, alternatively to the logic of substitution, we assume a logic of updating and expanding the ways of teaching and learning with digital games and, no less, of their design and conception.

\section{References}

BEN 10. In: WIKIPÉDIA: a enciclopédia livre. [2020]. Disponível em: https://cutt.ly/rQOSRi1. Acesso em: 20 jan. 2021.

COUTINHO, F. A.; SILVA, F. A. R.; MATOS, S. A.; SOUZA, D. F.; LISBOA, D. P. Proposta de uma unidade de análise para a materialidade da cognição. Revista SBEnBlo, Florianópolis, v. 7, p. 1930-1942, 2014.

COUTINHO, F. A.; SILVA, A. P.; SANTIAGO, F. F.; FARIA, E. S. As ontologias de um desastre ambiental: um estudo sobre uma controvérsia instaurada em uma licenciatura do campo. Investigações em Ensino de Ciências, Porto Alegre, v. 22, n. 1, p. 222-236, 2017. DOI: https://doi.org/gq6k.

COUTINHO, F. Â.; VIANA, G. M. Alguns elementos da Teoria Ator-Rede. In: COUTINHO, F. Â.; VIANA, G. M. (org.). Teoria ator-rede e educação. Curitiba: Appris, 2019. p. 17-33.

COUTINHO, I. J. Jogos digitais como espaço de aprendizagem: desafios para a formação docente. In: ENCONTRO INTERNACIONAL VIRTUAL EDUCA BAHIA, 19., 2018, Salvador. Anais [...]. Salvador: 2018. Disponível em: https://cutt.ly/IWOMcCr. Acesso em: 27 nov. 2020.

CRUZ, G. R.; LIMA, M. R.; NASCIMENTO, S. S. Jogos eletrônicos na formação de professores: uma revisão sistemática no Portal de Periódicos da Capes. Teoria e Prática da Educação, Maringá, v. 23, n. 2, p. 117-141, 2020. DOI: https://doi.org/gq6h.

EGENFELDT-NIELSEN, S. The challenges to diffusion of educational computer games. In: CONNOLLY, T. (ed.). Leading issues in games based learning. Readink, UK: Academic Publishing International, 2011. p. 141-158.

FENWICK, T. Knowledge circulations in inter-para/professional practice: a sociomaterial enquiry. Journal of Vocational Education and Training, London, v. 66, n. 3, p. 264-280, 2014. DOI: https:// doi.org/gq6m.

FREIRE, L. L. Seguindo Bruno Latour: notas para uma antropologia simétrica. Comum, Rio de Janeiro, v. 11, n. 26, p. 46-65, 2006.

HEINSFELD, B. D.; PISCHETOLA, M. Cultura digital e educação, uma leitura dos estudos culturais sobre os desafios da contemporaneidade. Revista Ibero-Americana de Estudos em Educação, Araraquara, v. 12, n. n.esp. 2, p. 1349-1371, 2017. DOI: https://doi.org/gq6q.

KNAPPETT, C. Thinking through material culture: an interdisciplinary perspective. Philadelphia: University of Pennsylvania Press, 2005.

LATOUR, B. A esperança de Pandora. Bauru: EDUSC, 2001.

LATOUR, B. Jamais fomos modernos. São Paulo: Ed. 34, 1994.

LATOUR, B. Por uma antropologia do centro. Mana, Rio de Janeiro, v. 10, n. 2, p. 397-413, 2004. DOI: https://doi.org/bwwnvd.

LATOUR, B. Reagregando o social: uma Introdução à teoria do ator-rede. Salvador: EDUFBA, 2012.

LATOUR, B.; VENTURINI, T. O tecido social: rastros digitais e métodos quali-quantitativos. In: OMENA, J. J. Métodos digitais: teoria-prática-crítica. Lisboa: Icnova, 2019. p. 37-46.

LAW, J. Aircraft stories: decentering the object in technoscience. Durham: Duke University Press, 2002. 
LEMOS, A. A comunicação das coisas: teoria ator-rede e cibercultura. São Paulo: Annablume, 2013.

LEMOS, A. Epistemologia da comunicação, neomaterialismo e cultura digital. Galáxia, São Paulo, n. 43, p. 54-66, 2020. DOI: https://doi.org/gkxwqn.

LEMOS, A. Mídia, tecnologia e educação: atores, redes, objetos e espaço. In: LINHARES, R. N.; PORTO, C.; FREIRE, V. Mídia e educação: espaços e (co)relações de conhecimentos. Aracaju: EdUNIT, 2014. p. 11-28.

LIMA, M. R. Projeto UCA e plano CEIBAL como possibilidades de reconfiguração da prática pedagógica com as tecnologias digitais de informação e comunicação. 268 f. 2015. Tese (Doutorado) - Universidade Federal de Minas Gerais, Belo Horizonte, 2015. Disponível em: https://cutt.ly/IQAAdbe. Acesso em: 4 ago. 2020.

LIMA, M. R.; MENDES, D. S.; LIMA, E. M. Exergames na educação física escolar como potencializadores da ação docente na cultura digital. Educar em Revista, Curitiba, v. 36, p. e66038, 2020. DOI: https://doi.org/gq6r.

MORAES, D. A. F.; LIMA, C. M. O estudante e sua relação com as tecnologias digitais: representações em sua aprendizagem. Revista Teias, Rio de Janeiro, v. 19, n. 53, p. 299-313, 2018. DOI: https://doi.org/gq6s.

NEWZOO. Rankings: top companies and countries by game revenue, top grossing apps, PC games, and more. [2020]. Disponível em: https://newzoo.com/insights/rankings/. Acesso em: 11 dez. 2020.

OLIVEIRA, K. E. J.; PORTO, C. M. Educação e teoria ator-rede: fluxos heterogêneos e conexões híbridas. Ilhéus: Editus, 2016.

REIS, V.; SCHNELL, R. F.; SARTORI, A. S. Big data, psicopolítica e infoética: repercussões na cultura e na educação. PerCursos, Florianópolis, v. 21, n. 45, p. 50-79, 2020. DOI: https://doi.org/gq6v.

SANTAELLA, L. A cultura digital na berlinda. In: LOPES, M. I. V.; KUNSCH, M. M. K. (org.). Comunicação, cultura e mídias sociais. São Paulo: ECA-USP, 2015. p. 93-101.

SISMONDO, S. An introduction to science and technology studies. Oxford: Wiley-Blackwell, 2010.

SØRENSEN, E. The materiality of learning: technology and knowledge in educational practice. New York: Cambridge University Press, 2009.

STRAUSS, A.; CORBIN, J. Pesquisa qualitativa: técnicas e procedimentos para o desenvolvimento de teoria fundamentada. 2. ed. Porto Alegre: Artmed, 2008.

THIOLLENT, M. Metodologia da pesquisa-ação. 7. ed. São Paulo: Cortez, 1996.

VENANCIO, B.; VIANA, G. M.; SILVA, F. A. R. Seguindo o rastro do tempo: um estudo ator-rede de performances de práticas de ensino de licenciandos em ciências biológicas. Actio: docência em ciências, Curitiba, v. 5, n. 3, p. 1-19, 2020. DOI: https://doi.org/gq6x. 